However, there has not appeared any spirit to take unfair advantage of the state's liberality, and many of the patients say at once that they can afiord to buy these necessary supplies themselves. Nor are any cases treated at the dispensary who can afford to pay a private physician. The act provides that the state dispensaries are for "indigent" consumptives, and those who can pay are referred back to their regular physicians. Otherwise, it would be most unfair to the general practitioner.

But to show the extent of the state's bounty to indigent consumptives, it may be interesting to say that between January 7 and May 17,480 quarts of milk and 2,485 dozen eggs have been distributed gratuitously. Az the work grows these figures will no doubt look small, for as long as there are deserving patients willing to do their best to get well from the disease the state stands ready to do its part in the cure.

Finally, while I believe the vast resources which the State of Pennsylvania has made available for this work, and the splendid organization being built up by the commissioner, now make the state work the most important factor in the crusade in Pennsylvania; yet we must not forget that it is by no means the only force at work, and I should be falling far short of telling all, did I not point to the Pennsylvania Society for the Prevention of Tuberculosis and the other private organizations and institutions at work in this field. They have done much and they will do more. It is the educational work gone before which rendered possible the state's action.

But the state can not accomplish the result alone, nor can the private institutions and organizations. Both are essential, both must be recognized. It is by a united effort, by cooperation, by the harmonizing of all the agencies engaged in this noble work, that we may confidently expect to accomplish our purpose-to see that day which is surely coming, when tuberculosis, from being the most widespread and destructive affliction of mankind, shall be an uncommon malady.

\section{THE WHITE MAN IN THE TROPICS.}

\section{L. G. ANDERSON.}

WASHITGTON, D. C.

To those who are impelled by necessity, or induced by interest, to visit the torrid zone, and relinquish the blessings which fow from exercise in the delightful climates of the earth, in temperate vegions- to those who exchange their native countries, which yield the free and unbounded enjoyments of spontaneous health, for such as no care nor art can ever make agreeable-some cautions may be as no care nor art can ever make agreeable-some cautions may
necessary, some precepts useful.-DR. BENJAM IN MOSELY, 1787.

Le climat n'est dans point resserré dans les circonstances physigues attachées à chaque local, il est cet ensemble lui-même; et tous traits caractéristiques par lesquels la nature a distingué les diffêrent pays entrent dans l'idée que nous devons former du climatCABANIS.

The United States, with the assurance of robust youth, has entered the tropics, and assumes and presumes to dictate to alien peoples, residing in different elimes, their forms of government, trade regulations, modes of life, ethical standards, and to an extent, their religious beliefs.

However much I may sympathize with the natives of our tropical dependencies in having their repose and content disturbed, I acknowledge that my concern is not for them. The obligations of our government require a large number of white American men, women, and children to live and reside for long periods of time, or for life, under abnormal conditions which cause harm to themselves and deterioration of the race. These American citizens have received no warnings that unless their residence in the tropics is merely temporary, their children will be handicapped, and their grandchildren, if any, will see the finish of the family.

While necessity has compelled the authorities to heed the recommendations of medical officers to limit the service of soldiers and sailors in hot climates, yet the tendency in government reports and information about our tropical possessions is to paint them in rose color, to invite employés into the civil service, and to encourage permanent residence in these hot climates.

Human morbidity and mortality are greatest at the equator, and diminish as we approach the poles. This holds good for both natives and aliens. I do not believe much in statistics, but according to Cullimore, the annual death-rate is as follows:

From the equator to 20 degrees latitude, 1 death to each 25 inhabitants.

From 20 degrees latitude to 40 degrees latitude, 1 death to each 35 inhabitants.

From 40 degrees latitude to 60 degrees latitude, 1 death to each 43 inhabitants.

From 60 degrees latitude to 80 degrees latitude, 1 death to each 50 inhabitants.

By the tropics, I mean the equatorial zone extending around the earth between the Tropies of Cancer and Capricorn.

The inclination of the earth's rotative axis to the plane of the ecliptic measures about 23.30 degrees and is limited by the Tropic of Cancer in the northern hemisphere, and by the Tropic of Capricorn in the southern hemisphere. On June 21 the sun is vertical over the Tropic of Cancer. It then starts south, and about September 23 is directly over the equator. Continuing its southward journey, it reaches the Tropic of Capricorn about December 21, when it turns back toward the equator, which it crosses again about March 21 .

Outside these tropics, or turning points in the temperate and polar zones, the sun's rays can never fall vertically on the earth. Only between the tropics is the sun ever directly overhead. Practically, days and nights are equal near the equator and there is very little dawn or twilight.

As most of our heat is due to solarization, the long tropical day accounts for the greater heat, while the blanket of moisture always present prevents the radiation of heat by night. It should be particularly noted that these two conditions, heat and moisture, so favorable to the growth of bacterial life, are always present in the tropics, the only checks on the multiplication of inferior forms of life being warring species and lack of food. The latter is seldom wanting.

Every day is summer time in the tropics, and it is this continuous heat and humidity that is so enervating to the white races. In equatorial regions, vegetation, as a rule, is ever green, though the leaves are continually falling and being renewed.

Between the tropies lies one-third of the area of the earth, and four-fifths of this is ocean. Nine-tenths of the islands of the globe are situated within the tropics, and most of the mainland is in close proximity to the sea. This gives a marine climate, which means that the temperature is very equable (hot day and night) and that a high percentage of moisture ( $7_{5}$ to 95 per cent.) js always present. While the temperature rarely ranges above $95 \mathrm{~F}$. in the shade in the daytime, it seldom drops below $75 \mathrm{~F}$. at night. It is this constant association of heat and moisture and their unvarying persistence, together with the actinic effects of tropical light, that wear out white men in the tropics.

Instead of the four regular seasons of the temperate zones, there are but two seasons, dependent not on 
changes of temperature, but on a variation in the amount of raintall. In Spanish parts of the tropics it is customary to speak of the dry season as summer (verano), and of the wet season as winter (invierno). At some places this difference is marked, while at others they say that in the wet scason it rains all the time; in the dry season, only every day. This is literally true of certain sections, as along the coast of Veragnas; but there are other sites within the tropics, even on the seacoast, where rain seldom falls, as at Ceara on the northeast coast of Brazil, and at Aden on the Red Sea. In the Philippine Islands the wet and dry seasons, generally speaking, are each of about six months duration. In Panama and the Canal Zone the dry season lasts only three and a half months, extending from January 1 to April 15. In India, generally, the hot and dry season lasts from January 1 to June 1 of each year.

As a result of the greater heat at the equator the heated air rises while the colder air from the poles flows along the surface of the earth toward the equator. The rotation of the eartl from west to east changes these air currents into northeast and southeast winds, which are so constant in direction and duration as to be utilized by sailing vessels, and constitute the tradewinds of commerce.

Now it is a general law in meteorology that the windward side of mountains, especially if near the sea, is covered with fogs and drenched with rains, whereas the lecward side will be refreshed with the dry descending wind without precipitation. Fven where there is but a comparatively narrow strip of land between the oceans, as in Panama, this difference obtains. The annual rainfall at Colon is about twelve feet, while across the low divide at the city of Panama, on the Pacific Coast, only forty miles away, the rainfall is but six feet and sometimes less. So the climate of a place is the sum or resultant of its latitude, altitude, topography and geology of its soil, proximity to sea or mountain, prevailing winds, humidity and precipitation, sunshine or cloudiuess and clectric states of earth and atmosphere. The stage of civilization and sociologic conditions of the people have a large influence on the welfare of strangers.

A saving factor in the tropics is altitude, each 250 feet of elevation being equivalent to one degree of latitude from the equator. Much of the land area between the tropies, comprising the elevated plains and mountain ranges, while geographically tropical, climatologically is temperate. It is only on these plateaus that the white man has been able to establish himself, and it has been only the Iuatin race, particularly the Spaniard, who has been able to do this. Quito, Bogota, San José de Costa Rica, Guatemala City and Mexico City, though between the tropics, do not suffer from tropical climates; and in these capitals the Spaniard has taken root. The climate of Petropolis is radically different from that of Rio de Janeiro a few miles away. Benguet differs from Manila, and Simla and Jardeeling from Calcutta, Míadras and Bombay.

The English are still exotic in India; the Spaniard remains a-resident in tropical America. The Spanish people, by reason of their southerly origin and skin pigmentation, the best fitted of Europeans to colonize the Tropics, have failed, except on the plateaus and in the high valleys; and even there it is largely by fusion with the native Indian thus forming a race of mestizos or hrbrids, that they have been enabled to perpetuate their kind. On the coastal plains (the purely tropical sec- tions), the Spaniard has not been able to maintain a footing.

Africans are in possession of the West Indies. Th? old and populous cities of the Spanish main are now given over to the negro and negroid mixtures. To-day, Cartagena, Colon, Bocas del Toro, Puerto Limon, l’ortau-Prince, Bridgetown, and Kingston, are inhabite.1 mostly by negroes. A few places, like Panama and Manila, are so important as trade-centers, or seats of government, that white races keep them alive by a constant renewal of fresh blood.

For several hundred years the populous white races of Europe have had plenty of room to expand in the temperate zones: in the United States, Canada, Argentina, Chile, Australia, and Siberia. The populations of all the large cities in the temperate zones are congested. The outlet is in the direction of least resistance and where nature beckons kindly.

The world is becoming crowded. The inhabitants of the earth have doubled during the last hundred vears. Not simply in certain congested areas as formerly, but in all the pleasant places of the earth, arable lands in temperate zones, tillable profitably under natural conditions, are now mostly occupied. Intensive farming, irrigation of arid tracts, and reclamation of swamps, will furnish relief for a number of years.

The natural boundaries which separated nations and races have been effaced by steam and electricity. The sea, instead of being a barrier, has become a broad, frictionless highway for quick and easy access. Mountain chains have been tunneled, and wide deserts travcreed by railroads. Aerial transportation lies within the near future.

Commercial strife between nations is now acute. Warring strife between races is inevitable. The lands of the tropics are the richest in the world, and yield the greatest return for the least labor. It would seem that here is the natural outlet for the tension in the temperate zones, and a fertile field for conquest.

For control, yes; for colonization, never! The tropics belong to the colored races, and in them they must work out their own salvation through the slow evolution of the centuries.

No white colony has been able to maintain an independent existence in the tropics. When whites invade the torrid zone, they must first subjugate and combat the colored natives, and then keep up a continuous warfare with nature. Under free competition, whites can not compete with blacks within the tropies; and it is only by control of the colored natives, equivalent to enslavement, that white men can exist in the tropics and keep up stable and efficient government. To-day there is control and regulation of the persons and labor of the colored natives in all well regulated tropical countries.

England governs India by relays of officials from home, and not by representation. She is particularly careful not to disturb racial, tribal, or caste customs, and her control will collapse whenever a united India is formed. Even in our sister republic of Mexico, men are practically bought and sold, and can go away from plantation or mine only on pass. This is as it should be. The natives have neither the desire, intelligence, nor energy to govern themselves according to our standards; the white man can furnish the brains, but can not keep up manual labor in the tropics; so there is a fair exchange of efficiency.

To force on an unwilling people a foreign form of 
government always results in failure. To attempt to force free government and American institutions on colored barbarians, as we are trying to do in the Philippines, is not only an expression of gross ignorance, but cistinctly unnatural, criminal, and sinful. To assume that an act of Congress, or that the proclamation of a president, however benevolent, can replace the gradual evolution of ages, is to deny the data of science and the teachings of history. The idea or theory that we can by legislation ingraft on the people of the tropics those principles of government and standards of civilization which obtain among northern races, seems to me as crroncous and presumptuous as does the claim that by missions we can radically change their religious beliefs.

Since the pandemic of the fallacy of the equality of man, pseudo-statesmen, mushroom philanthropists, and false prophets of all kinds have been disturbing the natural course of nature in futile, but tiresome, and expensive attempts to abrogate the laws of nature. The new gospel of liberty induced the French to free the blacks in Haiti, and the negroes immediately massacred the whites on the island.

A great deal has been written by incompetent observers tending to show that white people can live well and continue to live well in the tropics. The general tenor and impression conveyed by United States official reports is that our intertropical dependencies are fitted for permanent residence by whites, and that the natives are competent for self-government. This sort of literature is positively harmful and dangerous.

Popular opinion in our country is soon expressed in Concress, and it enacts laws which are inapplicable in the tropics. While a few individual whites may even be benefited by sojourn in the tropics, and many can pass rears there in comparative comfort, yet well marked iorlily changes always follow a long residence, and continue even on return to a cooler climate.

lieports by chiefs of service and premature gushing letters are equally misleading. The chiefs live under the best conditions, and make frequent visits to the states, or other temperate regions; the women are often carried to the transport on a stretcher. The correspondent who accepts passes on government steamers and entertainment at the hands of a steering committee becomes blind to the seamy side of things, and dwells on the beauties of waving palms and coral strands. Official and other anticipated inspections do not view usual conditions, and never the worst. Visiting congressmen, however good their intentions and great their zeal, get only snapshots from a steamer touching at the principal ports. They see only the coast towns, en fôte -palm arches, frothy oratory, and brass bands. When the visitors leave, the Filipino takes off his laundered clothes, patent leather shoes, and derby hat, and reappears as he truly is - a semi-savage, with breech-clout and bolo.

Besides racial and climatic antagonisms, there is bound to be unrest from orders emanating from a seat of government far away, and ignorant of local conditions in the colony. When the notion of independence has foolishly been encouraged among the natives, revolutions are bound to spring up periodically. Equality, independence, fire-arms, and fire-water are dangerous combustibles to put into the hands of a subject race.

Ilistory is full of the records of white colonies stranded and coming to grief in the tropics. When Europe awoke from the lethargy of the dark ages, and sailed beyond the Pillars of Hercules, it was along the equatorial belt that new lands were first discovered and settlements attempted. Prince Henry the Navigator and his followers crept down the coast of Africa, while with Italian pilots, Spain invaded tropical America, and was quickly followed by France, Holland, and England. In our expansion in the East and West Indies, we should not forget the dreadful price Europeans have paid for their holdings. The conquerors-Spanish, English, French, and Dutch-soon discovered that they could not work in the tropics as at home without disease and death, so they made the natives work for them -enslaved them. But here they made the fatal mistake of requiring a white man's work from a tropical Indian; so the natives perished rapidly.

When we consider the effects of change of climate and season on the physical features of the earth, and on animal and plant life, it is really wonderful to behold man charging around the globe, and nearly from pole to pole, seeking conquest, fame or riches. Man can live under the most diverse conditions, but he can not there develop his best qualities and propagate robust offspring.

I assume that it is unnecessary to prove that the races of mankind thrive, develop, and reach perfection within well defined climatic areas. Fauna and fiora can only exist and persist as distinct species inside certain zones bounded by isotherms. 'The whole scheme of nature is to preserve and perfect the race at the expense of defoctive individuals, and to perpetuate that race or pcople who are best adapted to live under the conditions of a given environment. This environment in course of time becomes the natural habitat for those people. When races emigrate from their natural habitat and try to live under strange conditions, they perish; their blood may be continued by union with native stock; or the survival of the fittest under the new environment may propagate another kind of people. In either case, the characteristics of the old race (immigrants) are lost. The mongrel results of miscegenation are seen all over the tropics in places where a purely white race can not persist.

Health, strength, and long life result only from harmony between the individual and the universe that surrounds him. The same rule applies to race. The common belief, that after a few months' residence in the tropics the white man becomes "acclimated," is erroneous. There is no such thing as acclimatization. By constant care and vigilance a man can adjust himself to his new surroundings, and may escape discomforts, ills, and dangers he would otherwise suffer. For a time, the white individual can do three to five times as much work as the native, but it is at the expense of the vitality he should transmit to his children, and preserve for age. In the tropies, weaklings die off or return home. Those who adjust themselves to the new environment may continue for a generation or two; but the white man seldom lasts beyond the third generation, and then sustained only by long visits home.

The tropics belong to the black and brown races, and there they have sense enough to remain. They have certain inherent rights, one of which is to be let alone; and if ruled, not to have northern ideas inflicted on them. The white man has no business in the tropics. When he occupies them he brings ruin to himself and misery on the natives.

It is unnecessary for us to speculate on or await the results of our own experiments in the tropics. We have at our doors, and partly within our territory, the 
West Indies. When first discovered by Europeans these islanc's supported a happy, gentle, joyous people, thorourhly in accord with surrounding nature. Hispaniola (Santo Domingo and Haiti) alone contained at least a million people. Spain began to enslave their bodies and save their souls. When tired of slaying the Indians, the Spanish soldiers hunted them with dogs, which fed on their flesh. When captured alive, the padres burnt th:m at the stake, holding the cross before their eyes. In twelve years there were not enough Indians left on II ispaniola to work the mines and plantations, so the Spaniards stole forty thousand natives from the Jalaras (Bahamas). These, too, were killed or committed suicide. Too late, they tried to save the Indian by importing the African. 'The negroes found the same, or a more favorable climate than in Africa; could stand, what the Indians could not, the white man's tasks; so they increased and multiplied, and now possess the islants of the Caribbean.

Sprain and France, separately and conjointly, owned San Domingo and Haiti, and each failed. Out of 32,090 soldiors, the French lost 15,000 men in two months, trying to recover IIaiti from the blacks; while at the same time Toussaint l'Ouverture died from the cold in a French fortress. 'The English then tried to establish thomselves on the island, but were driven out by the climate, with the loss of 45,000 men.

Jistory is filled with disasters from men getting out of their natural environment. Pizarro lost a fourth of his men by rerruga in the rarefied air of the high Anrles. Napoleon lost a large army in Russia, and another in Egypt, not so much from fighting as from the climate. Dr. Kane told us that "an Arctic night and an Arctic day age a man more harshly than a year anywhere else in all this weary world."

Formerly, service in the tropies was looked on almost as certain leath; the usual time for the disappearance of a regiment was five rears. Civilians suffered to a like extent. Of everv regiment of a thousand men sent to Jamaica, it was found that four to five hundred perished during the first eight months. A traveler recorls that out of a regiment stationed at Fort Aususta, Kingston, there were left only a quartermaster and a corporal.

Sir Francis Irake took the cities of Santo Domingo and Cartagena in 1286 , but lost so many men from disease that he was forced to retire. Many years later, in $1 \% 1$, the English again took Cartagena, but the climate drove them out. The same thing occurred at Havana, and the expedition against Santiago was abandoned on account of the mortality from disease.

After several attempts, Patterson's well-planned colony was driven from the isthmus of Panama by the climate, at the close of the seventeenth century.

In 1726 , Hosier lost heavily from disease before Porto Bello, and in 1 180 , General Darling captured the castle of San Juan with 1,800 men, but only 380 lived to get back to Jamaica. It was in this expedition that Nelson contracted his tropical liver.

Spain fought a losing fight with the tropics for four hundred years, and it was the climate, as much as the American soldiers, which finally drove her out of the West Indies and the Philippine Islands.

The flotas and galleons of Spain in the tropics were frequently rendered powerless by the ravages of disease. Notable examples were the losses under Don Domingo Justiniani, commodore of the Guarda Costas, at Santa Marta, in 1729; and those of the galleons of
Don Manuel Lopez Pintado, in 1730 before Cartagena. I am, of course, well aware of the rôle played by mosquitoes in the propagation and infection of at least two tropical diseases, and that by taking infinite pains under favorable conditions some of the dangers of the tropics can be eliminated. The essential factors of the climate, however, will always continue to exist.

As late as 1898, our magnificent little army, the Fifth Corps, went to pieces in six weeks before Santiago; anil if to-morrow we had to place a large force in the tropics, particularly in the face of an enemy, it woull I be practically impossible to apply prophylaxis against infection by mosquitoes, to say nothing of combating dysentery, plague, and cholera. If opposed by a nativa force, immune to the climate and diseases of the tropics, our handicap would be still greater.

In the tropics, the white man can not live with, compete with, nor govern the colored man, superior in numbers, under terms of political equality. After three hundred years of conquest and holdings, at the expenditure of thousands of lives and millions of money, the British are only hangers-on in the West Indies. In 1834, the English government emancipated their negroes, which was well, and paid the slave-holders without civil conflict, which was better and wiser than we did. But they committed the blunder of enfranchising the freed slaves, and thirty years later the United States repeated it.

By reason of liberty and the suffrage, Africans are actually in possession of most of the West Indies. The whites have found the conditions intolerable and unprofitable, while the blacks have rapidly increased anil acruired passive possession of the soil. In Barbados, the proportion of blacks to whites is as much as fifty to one. No wonder Great Britain is abandoning her forts and withholding her subsidies!

For years the labor of the West Indies and of the Guianas, has been done largely by Hindu coolies. These East Indians are imported under five-year contracts, and give satisfaction to their white cmployers. On being granted political equality, the negroes refused to work, and have degenerated into the most worthless people on the face of the earth. It is astonishing that the United States adopted this useless and discarded labor to build the Panama Canal. After three years' trial of the West Indian negro, the Canal Commission has been forced to replace him with the Spaniard, the Italian, the Hindu, and the Greek.

In our successful colonization in temperate zonesUnited States, Canada, Australia, Argentina-we have lost sight of the failures of our fellow emigrantsSpanish, French, Dutch, and English-in the tropics. The quick amalgamation of colonial America into the independent United States was not a result of the union of the white colonists with the native Indian, nor with the African, who came at the same time, but of the fact that Europeans found here the same climatic conditions under which they had lived and were bred. It is not from political or sociologic reasons that the negro has never flourished north of Mason and Dixon's line. Even the Spaniard, who at first had such a large share of the United States, and who then was the first rate power of the world, has been forced further south to his own environment.

There have always been statesmen and economists who considered colonies, and attempts at colonization, a burden, expense, and menace to the safety of the home government. Adam Smith, from the commercial point 
of view, had this to say about colonies: "After all the unjust attempts of every country in Europe to engross to itself the advantages of the trade of its own colonies, no country has yet been able to engross to itself anything but the expense of supporting in time of peace, and defending in time of war, the oppressive authority which it assumes over them."

We have at home so many evils to remedy and faults to correct that it would be well to refrain from attending to other people's business.

Americans have little regard for either the sanctity or the value of human life. Railroads, factories, mines, automobiles, and firetraps kill us by the hundreds; preventable filth discases, adulterated foods, polluted waters, and crowded habitations carry us off by the thousands every year. I affirm that we give Manila and Panama better sanitary supervision than we have in New York or Washington.

If we figure up, in lives and dollars, the cost of our expansion in the East and West Indies, it would be truly appalling. The four or five hundred millions we have spent on the Filipinos in the past ten years, expended with equal energy at home during the same period, would have abolished most of our tuberculosis, typhoid fever, and other avoidable diseases. We are justly called wasteful, spendthrift, and boastful. Must it also be said that we are an ignorant people, unmindful of the lessons of experience? Shall the verdict of nature and the teachings of history go unheeded?

\section{SUMMARY.}

1. When a spocies is well adapted to the conditions which environ it, it flourishes; when imperfectly adapted, it decays; when ill-adapted, it becomes extinct.

2. When a white man, native of a temperate zone, goes to the tropics, there occurs a biologic reaction of his system to the new environment, and a readjustment of co-ordination between his vital processes.

3 . In the tropics, the white man, individually, can exist; racially, he can not persist.

4. Acclimatization is not possible.

5. No superior race can successfully govern an inferior race, superior in numbers, with equality before the law.

6. Only by partial enslavement of the colored natives, superior in numbers, can the white man rule and govern the tropics, and it is only by relays of fresh representatives he can continue his sovereignty.

7. No colony of northern origin has ever been able to lead a permanent and independent existence in the tropics.

334 Indiana Avenue, N. W.

\section{THE USE OF GONOCOCCIC VACCINE IN TWENTY-SIX PATIENTS.}

\section{EDGAR G. BALLENGER, M.D.}

Lecturer on Genitourinary Diseases, Atlanta School of Medicine and Genitourinary Surgeon at the Presbyterian Hospital. atLANTA, Ga.

So satisfactory has been my experience with gonococcic "vaccine" or "bacterin" during the past few months that I desire to describe briefly my impressions regarding its use and to report the salient points from the histories of a few patients who have been cured by this treatment. I say cured by this treatment, for in spite of the fact that other measures as urethral injections and irrigations, internal medication and massage of the prostate were used in conjunction with the vaccine, the results were much more prompt than I had ever been able to obtain with these same remedies before beginning the use of the bacterins.

A free streaming of lymph, fresh from the circulation and laden with opsonins, should be promoted and maintained in every focus of infection. Wright has shown that the locality in which bacteria cultivate themselves is deficient in anti-bacterial substances on account of the sluggish circulation and the clotting of lymph in the sinuses. He also calls especial attention to the paraIytic action brought to bear on the leucocytes by the tryptic ferment liberated from the disintegrating pus cells in abscess cavities and sinuses, and to the futility of attempting to cure them by vaccine therapy unless they are emptied frequently and flooded with opsonic fluid fresh from the circulating blood. These facts are particularly illuminating when considered with the condition of affairs found in the inflamed prostate. Here we note the effect of the ferments liberated from the pus cells; the proteids being promptly converted into albumose which I have found to be present constantly in the inflamed prostate and to be of distinct value in the diagnosis of such conditions. A correlation of these facts readily shows that out treatment by prostatic massage has underlying it curative factors of which we were formerly unaware. The question of autoinoculation by massage of the prostate must also be considered. $\Lambda$ s the extent of such inoculations can not be known this part of the treatment or manipulations of gonococcal joints should not be done at the time of injecting the vaceine as an overdose may be thrown into the system.

We can not overestimate the importance of a careful examination in every instance and the institution of appropriate treatment along with vaccine therapy, which should be employed as an adjunct and not to supplant other forms of medication. Success will depend on the recognition of these conditions, on secondary infections and on the time at which the injections are made. Gonococcic bacterin only affects the gonococcus and may leave other micro-organisms to perpetuate the inflammation. For this reason microscopic examinations should be made and other vaccines injected or other measures employed to restrict the action of non-specific germs.

'The matter of "personal" or "stock" bacterin is one of considerable interest and importance. As far as $\mathrm{I}$ am able to judge from my own experience there is very little variation in the gonococcus and about as good results are obtainable with the stock vaccine as with the personal. The difference in the severity and course of the disease in different individuals is due almost entirely to the varying resistance of the host. I have used the stock vaccine marketed by Mulford \& Co., Philadelphia.

So far I have now given the bacterin treatment to twenty-six patients and feel no hesitation in saying that I have been able, in nearly all cases, to obtain more satisfactory results with it than with the various forms of treatment previously used. Eight of these patients had chronic prostatitis; two acute prostatitis; two epididymitis; one a periurethral abscess; three urethral stricture; three urethro-cystitis and one cystitis.

Until recently $I$ have not given the vaccine to patients during the acute stage of gonorrhea, but have waited until the subsiding stage. Injections of ten million gonococei were given to one patient, however, with a profuse discharge and very acute symptoms. He began to improve after the second injection and made an unusually quick recovery in spite of many disadvantages in 